\title{
Assessing impact of dams on genetic diversity of native fish Mastacembelus armatus in river Yamuna using mitochondrial DNA cytochrome-b sequences as a molecular marker
}

\author{
Thapliyal M. ${ }^{1}$, Sati B.K. ${ }^{2}$, Thapliyal A. ${ }^{3}$
}

Received: 05.03.2020

Revised: 16.05 .2020

Accepted: 20.05.2020

\begin{abstract}
Several dams have been constructed in Uttarakhand. In the present study an investigation on impact of dams on genetic diversity of native fish species Mastacembelus armatus at the Asan barrage on river Yamuna near Vikasnagar, Uttarakhand in India was done. Partial sequence of mitochondrial Cytochrome-b (Cyto-b) gene was used to determine the genetic variation in the population of Mastacembelus armatus. DNA was extracted from Mastacembelus armatus $(n=33)$ samples, collected from river Yamuna and its tributary Asan from fin and fishes were released back in their habitat. Cytochrome c oxidase I (COI) was used to ascertain the species of fish along with morphometric characters. Analysis of 324 bp mtDNA fragment of Cyto-b revealed the presence of 06 haplotypes with nucleotide diversity, value ranged from 0.0172 to 0.0021 low pair wise Fst value was observed negative (-0.00125) when compared between Asan barrage and Kalsi site. No genetic subdivisions between the population were found after or before the dam sites. Tajima's $D$ value for river Asan, site A1 Mirzapur (before dam) was -0.1167 (a negative value). Negative Tajima D value can be indicative of recent selective sweep or population expansion after a recent bottleneck and linkage to a swept gene. Our data shows that fragmentation of habitat by dams does not have any impact on the genetic diversity of non-migrating Mastacembelus armatus fish species.
\end{abstract}

Keywords: Anthropogenic activity, COI, Cyto-b, Garhwal Himalaya, Mastacembelus armatus

\section{Introduction}

Fragmentation of river systems by dams is increasing every day because of human needs. Dam related anthropogenic activities are severe but underappreciated threat to aquatic biodiversity (Araújo et al. 2018). Because of time lag and interactions with other factors (e.g. climate change), impacts of aquatic habitat fragmentation on aquatic ecosystems are not visible immediately, and therefore these impacts are underestimated. Managing freshwater biodiversity thus requires deliberate management of aquatic habitat fragmentation (Mantel et al. 2017). Studies of aquatic habitat fragmentation in river networks assume importance and these studies advance our general understanding of ecological fragmentation.

\section{Author's Address}

${ }^{1}$ Department of Zoology, Government PG College, Maldevta, Raipur, Dehradun, Uttarakhand, India.

${ }^{2}$ USERC, Govt. of Uttarakhand, Dehradun, 248002, Uttarakhand, India

${ }^{3}$ Department of Biotechnology, Graphic Era (Deemed to be University), NAAC "A"

Dehradun, 24002, Uttarakhand, India.

E-mail.: madhuthapliyal@gmail.com
Effects of river fragmentation due to various reasons are well known on migratory fishes (Brown et al., 2013; Leeuwen et al. 2018). Sometimes, naturally occurring waterfalls also impact the geographic distributions of aquatic species. Anthropogenic activity like damming, road building, water withdrawal, Hydro Electric Power (HEP) project divided aquatic habitats of rivers into smaller patches. Human actions influence almost every aquatic ecosystem across the globe and only a few rivers remain untouched (Benke, 1990). In some cases it has been so severe that even the dams had to be removed or alternative measures like fish ladders were made mandatory. At some places anthropogenic fragmentation is developing rapidly and this rapid pace sometimes does not provide enough time to aquatic species to adjust and evolve alongside thus affecting the rich biodiversity that is harbored within freshwater ecosystems (Fischer \& Lindenmayer, 2007). Changes in aquatic habitat also result in alteration in aquatic communities like macro invertebrates and aquatic flora that occur in the channel of natural rivers. Aquatic flora and 
fauna function in various ways and act as major force determining the species that can colonize particular aquatic ecosystem and following disturbances can alter drastically altering the biomass or, in extreme cases, eliminate species (James \& Barko, 1990).

Garhwal Himalaya (Latitude: 30.8728 Longitude: 79.0593), located in Northern part of India is a part of Indian Himalayan Region (IHR, extending from Jammu \& Kashmir to West Bengal of Indian Republic, (http://gbpihedenvis.nic.in/ indian_him_reg.htm). This region has several fresh water systems and one of the aquatic biodiversity components is represented by fishes. Fish populations located in the remote regions of IHR are among the unique populations as they have dwelled in these segregated geographical niches since the origin of Himalayan range. Various researchers have reported hypothesis related to fish species diversity \& richness patterns (Colwell \& Coddington 2000; Mora et al. 2014; Rodrigues et al. 2017). In recent years, ecologists and conservationists have unanimously accepted that humans are also impacting species due to their various activities (Goudie, 2018). Habitat pressure have been said to cause genetic diversity / variations in populations. In this context, anthropogenic activity during construction of dams is a major activity that creates severe pressure on aquatic habitat along with its inhabitants (Waples et al. 2008). In Garhwal Himalayan region, a phenomenal number of dams have been constructed and several are under construction and still more are in planning phase (Thapliyal et al., 2019). As no long term study, using molecular tools, has ever been carried out to study the population dynamics of fish species in the area therefore in present study we tried to investigate the genetic diversity of native fish species Mastacembelus armatus (Fig. 1) around Asan Barrage in river Yamuna.

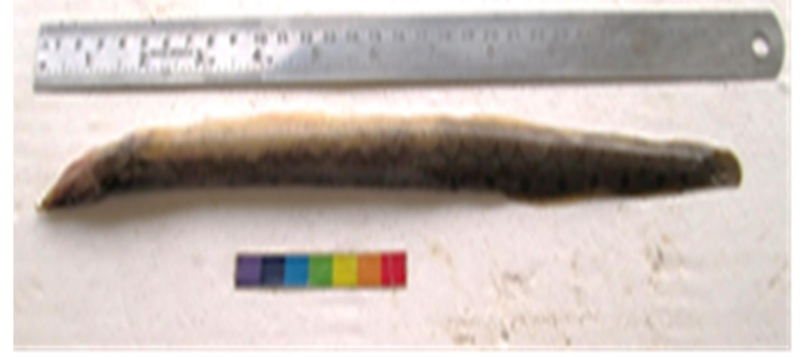

Fig. 1 Mastacembelus armatus

\section{Material and Methods}

\section{Sampling site:}

Samples were collected from river Yamuna and river Asan from various sampling sites using nets during April, 2012 - February, 2015 after due permission. At least 06 samples were sampled from each sampling station located at Mirzapur (code $\left.\mathrm{A} 1,29^{\circ} 58^{\prime} \mathrm{N} \& 7^{\circ} 11^{\prime} \mathrm{E}\right)$, before (code A2) and after (code A3) Asan Barrage $\left(30^{\circ} 43^{\prime} \mathrm{N}\right.$ \& $77^{\circ} 67^{\prime} \mathrm{E}$ ), Kalsi (code $\mathrm{Y} 1,30^{\circ} 51^{\prime} \mathrm{N} \& 77^{\circ} 84^{\prime} \mathrm{E}$ ), Poanta Sahib (code Y2, $30^{\circ} 44^{\prime} \mathrm{N} \& 7^{\circ} 61$ ' E) and merger point of river Asan and river Yamuna (code $\mathrm{Y} 3,30^{\circ} 43^{\prime} \mathrm{N}, \& 77^{\circ} 65^{\prime} \mathrm{E}$ ). A small piece of fin was taken and preserved in $80 \%$ alcohol until laboratory analysis. After sampling fishes were released into their natural habitat without harm. Samples size was standard, $n=6$, but this was in compliance with our efforts to protect biodiversity.

\section{DNA extraction, PCR and DNA sequencing:}

Total genomic DNA was isolated from fish fin by using the standard phenol-chloroform isolation protocol as used earlier by Thapliyal et al. 2015. In short, DNA was isolated from sample and checked on $1.5 \%$ Agarose Gel. 10 Micro L of isolated DNA was used to quantify the amount of DNA in sample by using UV spectrophotometer (Nanodrop). Isolated DNA from samples was used as templates to amplify specific target gene, COI, by Polymerase Chain Reaction (PCR) using Primers: Fish F1 (5'TCA ACC AAC CAC AAA GAC ATT GGC AC3') and Fish R1 (5' - TAG ACT TCT GGG TGG CCA AAG AAT CA - 3') (Ward et. al 2005). For population genetics, primers used were FP (5CACTGTAAAGCTAACTTAGC-3), RP (5AGAATGACAGTACTGCGG-3) which targeted for specific region of mitochondrial Cytochrome-b gene. PCR amplifications were performed using MJ research thermo-cycler (model - PTC-200) in a $50 \mu \mathrm{l}$ reaction consisting of: $5 \mu \mathrm{l}$ of $10 \mathrm{X}$ buffer (100mM Tris, pH 9.0, 500mM KCl, $15 \mathrm{mM} \mathrm{MgCl}_{2}$, $0.1 \%$ Gelatin) (Genei, India), $200 \mu \mathrm{M}$ each nucleotide (dNTP, Genei, India), 5pmole of each primer (Sigma Genosys, USA), $1.5 \mu 1$ high fidelity taq polymerase (Genei, India) and $1-2 \mu l$ of total DNA. The thermal regime consisted of an initial step of $3 \mathrm{~min}$ at $95^{\circ} \mathrm{C}$ followed by 34 cycles of $50 \mathrm{~s}$ at $94^{\circ} \mathrm{C}, 1 \mathrm{~min}$ at $54^{\circ} \mathrm{C}$ and $45 \mathrm{~s}$ at $72^{\circ} \mathrm{C}$, followed in turn by $10 \mathrm{~min}$ at $72{ }^{\circ} \mathrm{C}$. PCR products were stored at $4^{\circ} \mathrm{C}$. All PCR products were electrophoreses on 
$1.5 \%$ of Agarose gel followed by ethidium bromide staining and visualized under UV illumination (Fig $2 \mathrm{a}$ and $2 \mathrm{~b}$ ) in the Gel-Doc system (UVP) and purified using GeNeiTM Quick PCR purification kit (Genei, Bangalore, India). The PCR amplified fragments were cleaned for sequencing by using BigDye Terminator v.3.1 Cycle Sequencing Kit (Applied Biosystems, Inc.). The sample was then finally sequenced bi-directionally using an $\mathrm{ABI}$ 3130 Genetic analyzer (Applied Biosystems).
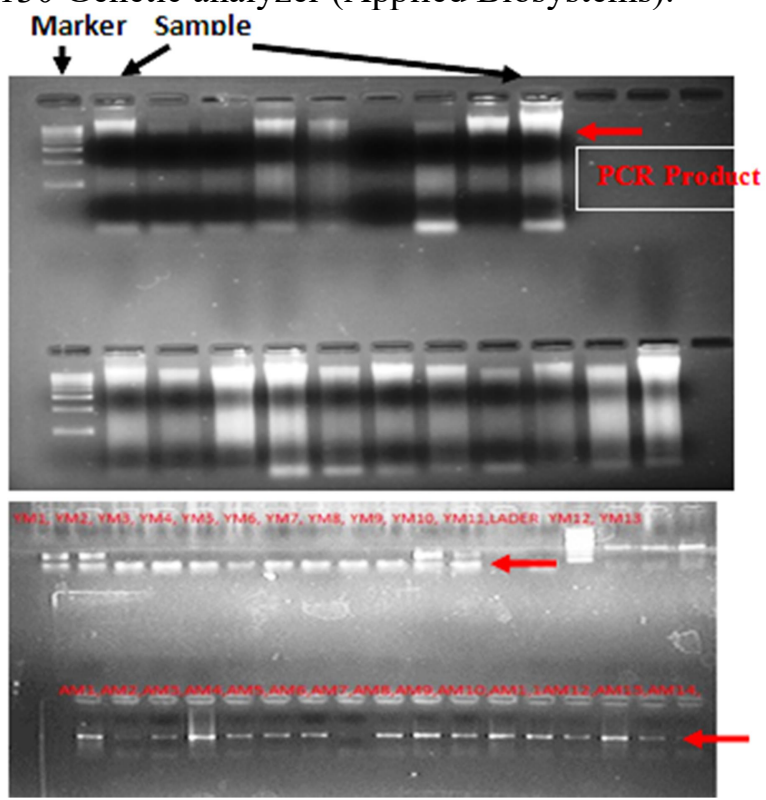

Fig. 2a. Cytochrome b mitochondrial DNA (sample loaded in Gel): Lane 1 is DNA marker:- Lane 2 onward Mastacembelus armatus samples from various location

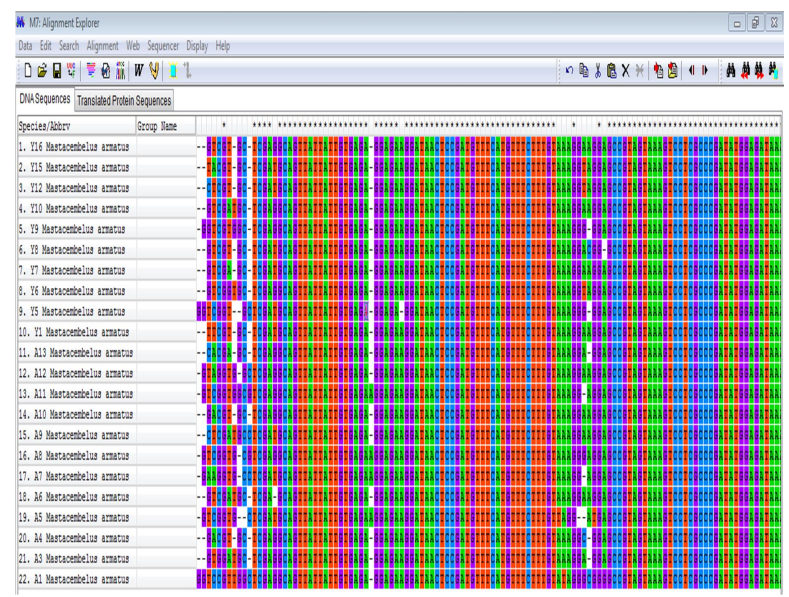

Fig: $2 b$ Cytochrome b sequences were aligned by Cluster Omega using Bio Edit v5.0 Sequence editor
Phylogenetic comparison among the sample was carried out using MEGA 7.0.9 software. These sequence data was used to analyze population diversity. Two parameters of population diversity namely haplotype diversity $(\mathrm{H})$ and nucleotide diversity $(\pi)$ indices were tabulated by using DnaSP v5.10 (Librado and Rozas, 2009) and Arlequin v3.5.1.2 (Excoffier and Lischer, 2010) software. The data generated through Arlequin software was further used to develop haplotype network using Network v4.6.1.1 software (Bandelt et al. 1999).

\section{Results and Discussion \\ COI based identification:}

A COI sequence of Mastacembelus armatus species were identified through COI based barcoding and identification technique, the sequence was then uploaded to the BOLD database/ NCBI with GenBank accession numbers: KC473940. The sequence was aligned using Clustal Omega and a sequence length of $651 \mathrm{bp}$ was used for comparison. The sequence was checked for insertions, deletions, or stop codons before analysis. The COI data combined with the morphometric analysis enabled us to ascertain the fish species.

Phylogenetic and molecular evolutionary analysis:

Phylogenetic and molecular evolutionary analysis was conducted using MEGA 7.0.9 (Molecular Evolutionary Genetics Analysis) (Tamura et al. 2013). The sequencing data obtained for Cyto-b gene from the samples was analyzed using distance NJ (Neighbour-Joining) and Maximum Parsimony (MP) methods (Mount, 2008). Maximum parsimony is a robust and most commonly used method to construct Phylogenetic tree, whereas neighbor joining is a clustering algorithm-based phylogeny approach which construct tree by clustering haplotype based on genetic distance. The sampling error of NJ and MP trees was analyzed using bootstraps of 500 replicates. Kimura twoparameter model (Kimura, 1980) was used to check the pairwise sequence divergence among samples. Transitions / transversions in sequences were also checked. The analysis clearly shows that haplotypes were not localized to specific geographical location but were scattered to all locations (Fig. 3).

\section{Data analysis and Sequence alignments:}


Analysis of Cytochrome b Sequence and genetic diversity:

Total 33 samples were used in the present study. A region of Cyto-b gene, which was 324 bp long, was amplified using PCR for Mastacembelus armatus. Both forward and reverse reads were obtained for each run and each sample was run two times to negate the sequencing errors. The amplified region was used to check the genetic variation among and within the geographically distinct populations of fish species. The sequence alignment was done using MEGA and Bio Edit v5.0 sequence editor. Sequences were analyzed using Arlequin software and the analysis revealed the presence of 06 haplotypes while the nucleotide diversity value ranged from 0.0172 to 0.0021 in Mastacembelus armatus (Table 1). Double population specific haplotype was observed in Yamuna and Asan. Data also found that these haplotypes were distributed across all sites.

Out of the 324 (bp) characters obtained 307 (96.03\%) were constant (Invariable sites) and 13 $(3.97 \%)$ were variable. The overall nucleotide base composition was as follows: $\mathrm{A}=14.88 \%, \mathrm{C}=$ $31.23 \%, \mathrm{G}=27.60 \%$ and $\mathrm{T}=26.29 \%$ and the $\mathrm{C}+$ $\mathrm{G}$ content were $58.83 \%$.

\section{Fst analysis:}

The sequences were analyzed and compared using Arlequin software for genetic variations in Mastacembelus armatus. Comparison of data from study site before Asan dam and study site located at the merger point to Yamuna and Asan River, showed variations. For Mastacembelus armatus, the Fst value ranged from 0.099 (After Asan Barrage A3 Vs. Merge to Asan Y3) to 0.981 (Mirzapur A1 Vs. After Asan Barrage A3). Lower Fst values between Merge to Asan and Ponta Sahib indicate

Table: 1 Cyto-b sequence divergence values for Mastacembelus armatus for populations from different sampling sites. Sequences were analyzed using Arlequin software to compute the number of haplotypes at each sampling site based on number of polymorphic sites in the sequences.

\begin{tabular}{|l|c|c|c|c|c|c|}
\hline Fish populations & \multicolumn{5}{|c|}{ Mastacembelus armatus } \\
\hline Parameters & & \multicolumn{5}{|c|}{ Sampling stations } \\
\cline { 2 - 7 } & $\begin{array}{c}\text { Mirzapur } \\
\text { (A1) }\end{array}$ & $\begin{array}{c}\text { Before Asan } \\
\text { Barrage (A2) }\end{array}$ & $\begin{array}{c}\text { After Asan } \\
\text { Barrage (A3) }\end{array}$ & Kalsi (Y1) & $\begin{array}{c}\text { Poanta Sahib } \\
\text { (Y2) }\end{array}$ & $\begin{array}{c}\text { Merge to Asan } \\
\text { (Y3) }\end{array}$ \\
\hline Number of Samples (n) & 6 & 5 & 5 & 5 & 6 & 6 \\
\hline $\begin{array}{l}\text { Number of Polymorphic } \\
\text { sites (PS) }\end{array}$ & 3 & 2 & 2 & 4 & 3 & 3 \\
\hline $\begin{array}{l}\text { Number of Haplotypes } \\
\text { (k) }\end{array}$ & 1 & 1 & 1 & 1 & 1 & 1 \\
\hline Haplotype diversity $(\mathrm{H})$ & 1.0000 & 1.000 & 1.000 & 1.000 & 0.666 & 1.000 \\
\hline Nucleotide diversity $(\pi)$ & 0.0172 & 0.0102 & 0.0096 & 0.0086 & 0.0021 & 0.0096 \\
\hline
\end{tabular}

42

Environment Conservation Journal that these populations underwent some significant amounts of genetic exchange events (Table 2). Also, based on the AMOVA analysis, the majority of the variation was found to be within populations of this species (Table 3). Fst Analysis also revealed a negative low pair wise Fst value $(-0.001258)$ between Kalsi (Y1) and after Asan Barrage (A3) which indicates that these populations underwent substantial genetic exchange events. This suggests that these locations were either connected at some point or the locations have regular floods and both these processes allowed mixing of populations.

The haplotype network of the samples from various locations was developed using Network v4.6.1.1 (Bandelt et al. 1999) software where the haplotypes pair wise differences were used to determine the number of mutational steps between haplotypes. Demographic expansion of $M$. armatus population in recent years at different sampling sites was checked using available molecular data. These tests were performed in Arlequin v3.1 using 1000 simulations under a selective model of neutrality and then the data was used to generate the haplotype network. This statistical test is designed to distinguish naturally evolving sequences (as naturally occurring mutation in sequences of specific genes and genome) from the changes in sequences that happen under non-neutral processes (including directional and balancing selection and demographic expansion or population contraction) (Ramos-Onsins and Rozas 2002, De Jong et al. 2011). The analysis suggests that these fishes from different locations were likely derived from different sources which have now merged and as they have genetic characters that are spread across all populations (Fig-3 \& Fig. 4). 
Impact of dams on genetic diversity of native fish Mastacembelus armatus

Table 2: Population pair wise Fst comparisons for Mastacembelus armatus (below the diagonal) from different sampling sites.

\begin{tabular}{|l|l|l|l|l|l|l|}
\hline Sampling stations & $\begin{array}{l}\text { Mirzapur, } \\
\text { (A1) }\end{array}$ & $\begin{array}{l}\text { Before Asan } \\
\text { Barrage(A2) }\end{array}$ & $\begin{array}{l}\text { After Asan } \\
\text { Barrage(A3) }\end{array}$ & Kalsi (Y1) & $\begin{array}{l}\text { Poanta } \\
\text { (Y2) }\end{array}$ & $\begin{array}{l}\text { Sahib } \\
\text { Merge to } \\
\text { Asan (Y3) }\end{array}$ \\
\hline Mirzapur, (A1) & 0.00 & & & & \\
\hline $\begin{array}{l}\text { Before Asan } \\
\text { Barrage(A2) }\end{array}$ & $\begin{array}{l}0.78378 \pm 0.03 \\
85\end{array}$ & 0.00 & & & & \\
\hline $\begin{array}{l}\text { After Asan } \\
\text { Barrage(A3) }\end{array}$ & $\begin{array}{l}0.94595 \pm 0.02 \\
05\end{array}$ & $\begin{array}{l}0.65766 \pm 0.04 \\
90\end{array}$ & 0.00 & & \\
\hline Kalsi (Y1) & $\begin{array}{l}0.98198 \pm 0.00 \\
96\end{array}$ & $\begin{array}{l}0.96396 \pm 0.01 \\
96\end{array}$ & -0.001258 & 0.00 & \\
\hline Poanta sahib (Y2) & $\begin{array}{l}0.42342 \pm 0.05 \\
26\end{array}$ & $\begin{array}{l}0.35135 \pm 0.04 \\
78\end{array}$ & $\begin{array}{l}0.35135 \pm 0.06 \\
97\end{array}$ & $\begin{array}{l}0.30631 \pm 0.04 \\
11\end{array}$ & 0.00 & \\
\hline $\begin{array}{l}\text { Merge to Asan } \\
\text { (Y3) }\end{array}$ & $\begin{array}{l}0.32432 \pm 0.03 \\
88\end{array}$ & $\begin{array}{l}0.13514 \pm 0.03 \\
11\end{array}$ & $\begin{array}{l}0.09910 \pm 0.02 \\
52\end{array}$ & $\begin{array}{l}0.50450 \pm 0.04 \\
33\end{array}$ & $0.23423 \pm 0.0388$ & 0.00 \\
\hline
\end{tabular}

*significant $p$ values $(<0.05)$.

Table: 3 Analysis of molecular variance (AMOVA) analysis for Mastacembelus armatus based on mitochondrial Cytochrome b region. The data shows that the majority of the variations occur within populations for this species.

\begin{tabular}{|l|l|l|l|l|}
\hline Source of variation & d.f. & Sum of components & Variance components & Percentage of variation \\
\hline Among group & 1 & 8.262 & $0.33129 \mathrm{Va}$ & 5.81 \\
\hline Within populations & 16 & 90.167 & $5.63542 \mathrm{Vb}$ & 98.90 \\
\hline Total & 17 & 98.429 & 5.96671 & - \\
\hline
\end{tabular}

Va-Variation among group $\mathrm{Vb}$-Variation within population

*Significant $\mathrm{p}$ values $(<0.05), * *$ Significant $\mathrm{p}$ values $(<0.01)$.

Table: 4 A statistical Neutrality Test initially developed to analyze selective neutrality of mutations was implemented to test demographic expansion of Mastacembelus armatus in different Population. One site on the River Asan, site A1 (before dam) showed a negative Tajima D value. which implies that rare alleles are present at high frequency (excess of rare alleles)

\begin{tabular}{|l|l|l|l|l|l|l|l|l|}
\hline & \multicolumn{2}{|l|}{ Mastacembelus armatus } \\
\cline { 2 - 9 } & $\begin{array}{l}\text { Mirzapur, } \\
\text { (A1) }\end{array}$ & $\begin{array}{l}\text { Before Asan } \\
\text { Barrage(A2) }\end{array}$ & $\begin{array}{l}\text { After Asan } \\
\text { Barrage(A3) }\end{array}$ & Kalsi (Y1) & $\begin{array}{l}\text { Poanta } \\
\text { Sahib (Y2) }\end{array}$ & $\begin{array}{l}\text { Merge to } \\
\text { Asan } \\
\text { (Y3) }\end{array}$ & Mean & S.D. \\
\hline Tajima's D & -0.11674 & 1.53598 & 0.69482 & 0.00000 & 0.00000 & 0.52223 & $\begin{array}{l}0.4393 \\
8\end{array}$ & 0.62770 \\
\hline $\begin{array}{l}\text { Tajima's D } \\
\text { p-value }\end{array}$ & 0.60900 & 0.90100 & 0.79200 & 1.00000 & 1.00000 & 0.74200 & $\begin{array}{l}0.8406 \\
7\end{array}$ & 0.15504 \\
\hline Fu's FS & 0.93592 & 0.52896 & 0.46229 & 1.33223 & 3.47266 & 0.01708 & $\begin{array}{l}1.1248 \\
5\end{array}$ & $\begin{array}{l}1.23387 \\
\text { FSp-value }\end{array}$ \\
\hline
\end{tabular}


Thapliyal et al.

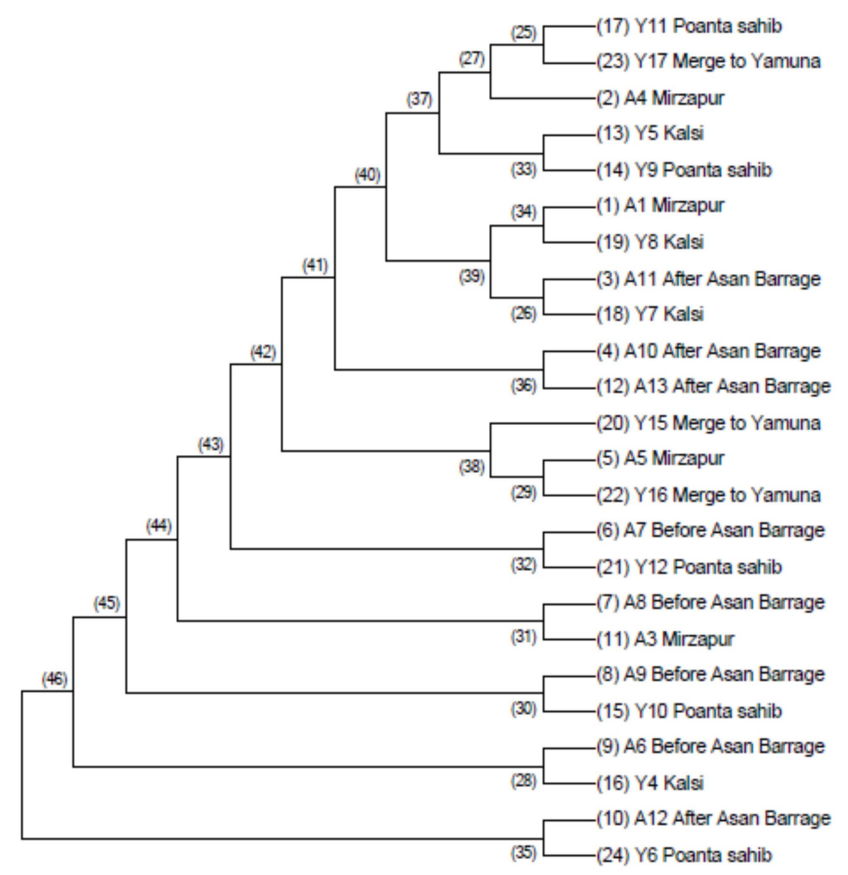

Fig: 3 Analysis of phylogenetic relationship between samples from various locations was carried out using Neighbor-Joining method (MEGA software, Bootstrap value obtained from 500 replicates). Analysis clearly shows that haplotypes were not localized to specific geographical location but were scattered to all locations.

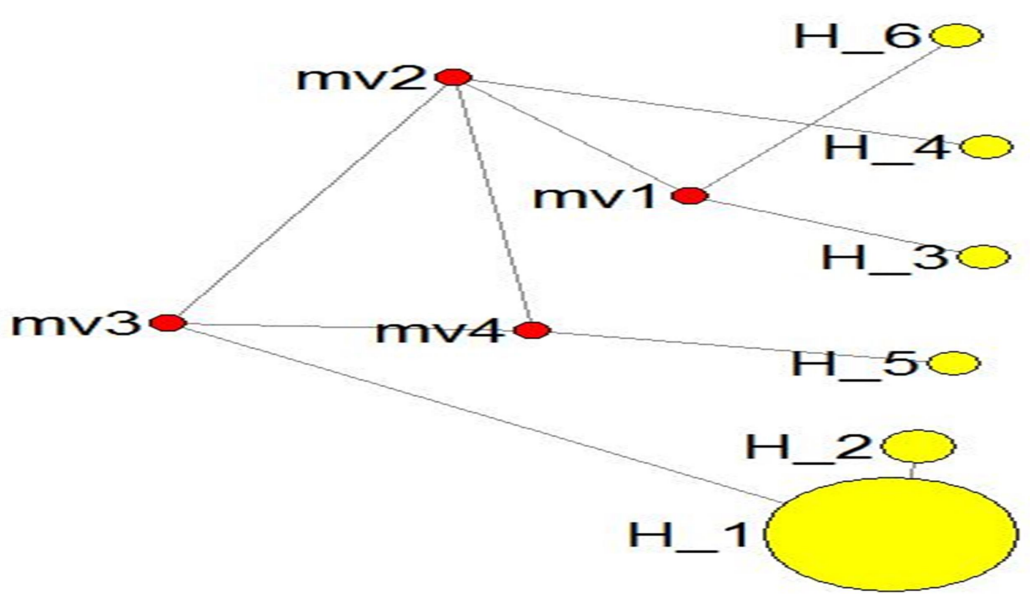

Fig: 4 Haplotype network of Mastacembelus armatus populations generated through throug Network v4.6.1.1 software. The network map strongly suggests that these fishes were likely derived from different sources and they have mixed haplotype distribution. The data suggests that the sampled fishes were likely derived from different sources which have now merged and they have common genetic characters that are spread across all populations. 
The Cytochrome-b sequence data of Mastacembelus armatus were used in the present study and the fish samples were collected from river Yamuna and its tributary, river Asan, in Dehradun district. The specific 324 bp long region of Cytochrome-b was amplified using universal primers (Kocher, 1993). These primers have been used by other investigators also and they have been reported as useful tools in detecting intraspecific variation in several species. Most represented bases were in the following order; $\mathrm{C}<\mathrm{A}<\mathrm{T}<\mathrm{G}$ in Cyto-b sequence of Mastacembelus armatus. Nucleotide Sequences of Cytochrome-b Mastacembelus armatus have CG content as $58.83 \%$. The $324 \mathrm{bp}$ region of Cyto-b gene that we have used in our study is polymorphic and has been used successfully for intra specific genetic diversity analysis in various fish species, like Salmotrutta (Apostolidis et al. 1997), Actinopterygii (Buj et al. 2014) and Latesca lcariferosteo brama belangeri. AMOVA analysis revealed high within population variation in Mastacembelus armatus (98.90\%) and low among group variation $(5.81 \%)$. It is usually seen that the migrating fishes have a higher genetic divergence. Our analysis reveals that in case of Mastacembelus armatus, the genetic divergence level between populations was even higher than that reported for a migratory fish. Results of Fst analysis also support the presence of significant genetic difference between populations of river Yamuna between Kalsi (Y1) and after Asan Barrage (A3). A negative Fst value (of -0.001258) indicates that these populations underwent substantial genetic exchange events. The data suggests that it is likely that the populations being studied evolved after fragmentation from common ancestors and these ancestors spread to various locations due to anthropogenic pressure that was created during construction of Asan dam/barrage. Moreover, keeping the topography of the area in view of these study sites, it seems that at the location of merger point of river Asan onto river Yamuna, if the water levels exceed certain height, the area could have caused the populations to mix for a brief period resulting in distribution of haplotype uniformly in all sites. It is hence evident that populations of Mastacembelus armatus belong to common ancestral populations that are distributed uniformly.
Impact of habitat fragmentation by dams on genetic diversity has been well studied and most of the studies argue that the genetic diversity is reduced (Yamamoto et al, 2004, Morita et. al, 2009, Excoffier and Lischer 2010, Bouzat 2010, Fuller et al. 2015, Pavlova et. al, 2017, Barborossa et. al., 2020, Pereira et. al., 2020). However, authors have also reported that in some cases because of factors like permeability, the length of river that is fragmented and the ability of particular species to adapt fast, the dam related effect on genetic diversity can be counterbalanced (Reid et. al, 2008, McDermid et. al., 2014).

\section{Conclusion}

In our study, the River Yamuna (including its tributary river Asan) was selected as the study site because there has been extensive fragmentation of aquatic habitat in this region due to anthropogenic activity. The results clearly show that anthropogenic activity had almost no impact on genetic diversity and that habitat fragmentation due to dams has not led to segregation or genetic differences in population of Mastacembelus armatus. We hypothesize that the fish species inhabiting the unique Himalayan ranges have evolved plasticity of genome to accommodate drastic pressures of environment which might be due to several processes like flash flooding (either due to cloud bursts or due to lake formation after landslides in river valley's ) or huge overflow of water during rainy seasons.

\section{Acknowledgement}

The authors thank Dr. S.P Goyal, Emeritus, Wildlife Institute of India (WII), Chandrabani, Dehradun, for lending his expertise and scientific help. Scholarship during Ph. D. work granted to Dr. Bipin Kumar Sati by Graphic Era (Deemed to be University) is acknowledged. Thanks to Mr. Deepak Rawat, Chief Librarian, Graphic Era for carrying out plagiarism check.

\section{References}

Apostolidis, A.P., Triantaphyllidis, C., Kouvatsi, A. and Economidis, P.S. 1997. Mitochondrial DNA sequence variation and phylogeography among Salmo trutta L.(Greek brown trout) populations. Mol. Ecol., 6(6):531542. 
Araújo, C.V., Silva, D.C., Gomes, L.E., Acayaba, R.D., Montagner, C.C., Moreira-Santos, M. and Pompêo, M.L. 2018. Habitat fragmentation caused by contaminants: atrazine as a chemical barrier isolating fish populations. Chemosphere, 193: 24-31.

Bandelt, H.J., Forster, P. and Röhl, A. 1999. Median-joining networks for inferring intraspecific phylogenies. Mol. Bio. and Evol., 16(1): 37-48.

Barbarossa, V., Schmitt, R.J., Huijbregts, M.A., Zarfl, C., King, H. and Schipper, A.M. 2020. Impacts of current and future large dams on the geographic range connectivity of freshwater fish worldwide. Proc. of the Nat. Acad. of Sci., 117(7), 3648-3655.

Benke, A.C. 1990. A perspective on America's vanishing streams. J. of the N. Am. Bentho. Soc., 9(1): 77-88.

Bouzat, J.L.. 2010. Conservation genetics of population bottlenecks: the role of chance, selection, and history. Cons. Gen., 11(2): 463-478.

Brown, J.J., Limburg, K.E., Waldman, J.R., Stephenson, K., Glenn, E.P., Juanes, F. and Jordaan, A. 2013. Fish and hydropower on the US Atlantic coast: failed fisheries policies from half-way technologies. Cons. Let., 6(4): 280286.

Buj, I., Šanda, R., Marčić, Z., Ćaleta, M. and Mrakovčić, M. 2014. Combining morphology and genetics in resolving taxonomy-a systematic revision of spined loaches (genus Cobitis; Cypriniformes, Actinopterygii) in the Adriatic watershed. PloS one, 9(6): e99833.

Colwell, R.K. and Coddington, J.A. 1994. Estimating terrestrial biodiversity through extrapolation. Philosophical. Trans. of the Roy. Soc. of Lond.. Series B: Biol. Sci., 345(1311): 101-118.

De Jong, M.A., Wahlberg, N., Van Eijk, M., Brakefield, P.M. and Zwaan, B.J. 2011. Mitochondrial DNA signature for range-wide populations of Bicyclus anynana suggests a rapid expansion from recent refugia. PloS one, 6(6): e21385.

Excoffier, L. and Lischer, H. E. Arlequin suite ver 3.5: 2010. A new series of programs to perform population genetics analyses under Linux and Windows. Mol. Ecol. Reso., 10(3): 564-567.

Fischer, J. and Lindenmayer, D.B. 2007. Landscape modification and habitat fragmentation: a synthesis. Glob. Ecol. and Biogeo., 16(3): 265-280.

Fuller, M.R., Doyle, M.W., \& Strayer, D.L. 2015. Causes and consequences of habitat fragmentation in river networks. Ann. of the N.Y. Acad. of Sci., 1355(1): 31-51.

Goudie, A.S. 2018 Human impact on the natural environment. John Wiley \& Sons.
James, W.F. and Barko, J.W. 1990. Macrophyte influences on the zonation of sediment accretion and composition in a north-temperate reservoir. Arch. für Hydrobiol., 120(2): 129-142.

Kimura, M. 1980. A simple method for estimating evolutionary rates of base substitutions through comparative studies of nucleotide sequences. J. of Mol. Evol., 16(2): 111-120.

Kocher, T.D., Conroy, J.A., McKaye, K.R. and Stauffer, J.R. 1993. Similar morphologies of cichlid fish in Lakes Tanganyika and Malawi are due to convergence. Mol. Phylog. and evol., 2(2): 158-165.

Leeuwen, V.C.H., Dalen, K., Museth, J., Junge, C. and Vøllestad, L.A. 2018. Habitat fragmentation has interactive effects on the population genetic diversity and individual behaviour of a freshwater salmonid fish. Riv. Res. and Appl., 34(1): 60-68.

Librado, P. and Rozas, J. 2009. Software for comprehensive analysis of DNA polymorphism data. Bioinformatics, 25(11): 1451-1452.

Mantel, S.K., Rivers, Moore, N. and Ramulifho, P. 2017. Small dams need consideration in riverscape conservation assessments. Aquatic Conservation: Mar. and Fresh. Ecosys, 27(4): 748-754.

McDermid, J.L., Nienhuis, S., Al-Shamlih, M., Haxton, T.J., \& Wilson, C.C. 2014. Evaluating the genetic consequences of river fragmentation in lake sturgeon (Acipenser fulvescens Rafinesque, 1817) populations. J. of Appl. Ichthyo., 30(6): 1514-1523.

Mora, C., Danovaro, R. and Loreau, M. 2014. Alternative hypotheses to explain why biodiversity-ecosystem functioning relationships are concave-up in some natural ecosystems but concave-down in manipulative experiments. Sci. Rep., 4: 5427.

Morita, K., Morita, S. H. and Yamamoto, S. 2009. Effects of habitat fragmentation by damming on salmonid fishes: lessons from white-spotted charr in Japan. Ecol. Res., 24(4): 711-722.

Mount, D.W. 2008. Maximum parsimony method for phylogenetic prediction. Cold Spring Harbor Protocols, 2008(4): pdb-top32.

Pavlova, A., Beheregaray, L.B., Coleman, R., Gilligan, D., Harrisson, K.A., Ingram, B.A. and Nguyen, T.T. 2017. Severe consequences of habitat fragmentation on genetic diversity of an endangered Australian freshwater fish: A call for assisted gene flow. Evol. Appl., 10(6): 531-550.

Pereira, H.R., Gomes, L.F., de Oliveira Barbosa, H., Pelicice, F.M., Nabout, J.C., Teresa, F.B. and Vieira, L.C.G. 2020. Research on dams and fishes: determinants, directions, and 
gaps in the world scientific production. Hydrobiologia, 847(2): 579-592.

Ramos-Onsins, S.E. and Rozas, J. 2002. Statistical properties of new neutrality tests against population growth. Mol. Bio.and Evol., 19(12): 2092-2100.

Reid, S.M., Wilson, C.C., Mandrak, N.E. and Carl, L.M. 2008. Population structure and genetic diversity of black redhorse (Moxostoma duquesnei) in a highly fragmented watershed. Cons. Gen., 9(3): 531.

Rodrigues, J.F.M., Olalla, Tárraga, M.Á., Iverson, J.B., Akre, T.S., and Diniz, Filho, J.A.F. 2017. Time and environment explain the current richness distribution of non marine turtles worldwide. Ecography, 40(12): 1402-1411.

Tamura, K., Stecher, G., Peterson, D., Filipski, A. and Kumar, S. MEGA6 2013. molecular evolutionary genetics analysis version 6.0. Mol. Bio. and Evol. 30(12): 2725-2729.
Thapliyal, M., Pokhriyal, H., Sati, B.K., Nagpure, N. S., Singh, M. and Thapliyal, A. 2015. Molecular characterization of coldwater fishes of district Uttarkashi, Uttarakhand using DNA Barcoding. Envi. Cons. J., 16(3): 109-116.

Thapliyal, M., Bahuguna, S.N. and Thapliyal, A. 2019. Adaptive skill of Schizothorax sp. of river Alaknanda under long term pressure of urbanization and anthropogenic activities in Garhwal Himalaya. Envi. Cons. J., 20(1\&2): 157-63.

Waples, R.S., Zabel, R.W., Scheuerell, M.D. and Sanderson, B.L. 2008. Evolutionary responses by native species to major anthropogenic changes to their ecosystems: Pacific salmon in the Columbia River hydropower system. Mol. Ecol., 17(1): 84-96.

Yamamoto, S., Morita, K., Koizumi, I. and Maekawa, K. 2004. Genetic differentiation of white-spotted charr (Salvelinus leucomaenis) populations after habitat fragmentation: spatial-temporal changes in gene frequencies. Cons. Gen., 5(4): 529-538. 